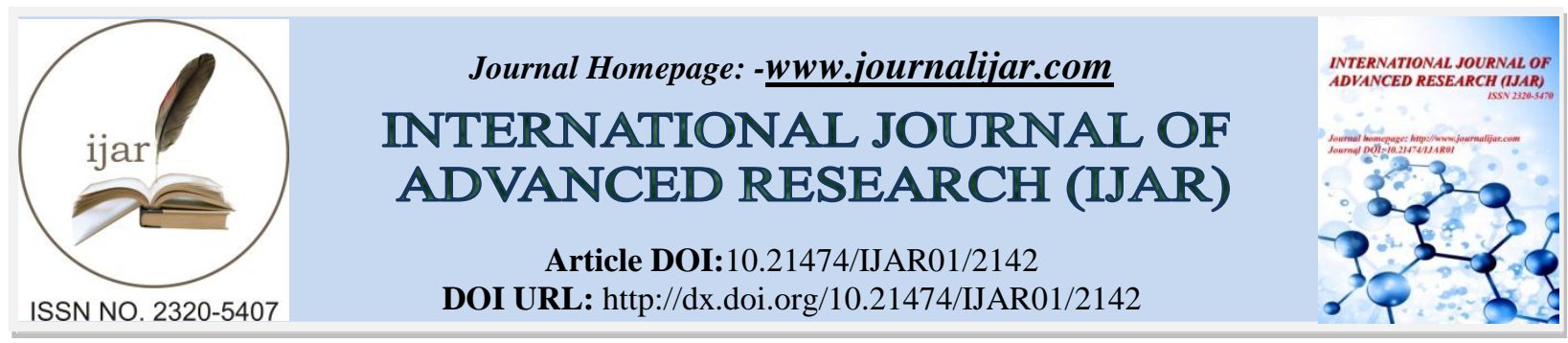

RESEARCH ARTICLE

\title{
CONSUMER ADOPTION OF INTERNET BANKING IN SRI LANKA
}

WasanthaPremarathne ${ }^{1}$ and M.M. Gunatilake ${ }^{2}$.

1. Department of Management and Finance, KotelawalaDefence University, Ratmalana, Sri Lanka.

2. Department of Economics, University of Kelaniya, Sri Lanka.

\section{Manuscript Info}

Manuscript History

Received: 25 September 2016

Final Accepted: 27 October 2016

Published: November 2016

Key words:-

Internet Banking, Commercial Banks,

Technophobia, Sri Lanka

\section{Abstract}

Internet Banking (IB) offers banksa new frontier of opportunities andchallenges in the contemporary global banking market. The demand for IBin Sri Lanka is relatively low despite the recent improvements of information and communication technology. The main purposes of this research paper are to explore and identify the factors which affect the adoption of IB in Sri Lanka. The present studyutilized bothprimary and secondary data to identify the determinants of demand for IB. A sample of customers; who are representing three leading commercial banks in Sri Lankawere selectedto collect primary data. The main analytical tool was an econometric model. The study revealed that the key determinants of consumer adoption and growth of IB in Sri Lanka are; the number of people who have access to internet facility, consumer awareness, web content and design, security, cost, technophobia, download speed, and customer preference of personalized services.

Copy Right, IJAR, 2016,. All rights reserved.

\section{Introduction:-}

Application of information and communication technology, concepts, techniques, and policies of banking services have become a subject of fundamental importance and a prerequisite for local and global competitiveness. The advancement in technology has played an important role in improving service delivery standards in the banking industry; yet, the usage of IB in Sri Lanka is stillat the minimum, compared tothe increase in the number of Internet users (Weerasekara, 2011).Despite the recent improvements in IB, some constraints, mainly security related issues and certain other factorshave made some individuals reluctantto adopt IB.

Arslan(2012) and Malhotra\&Singh (2007) reveal that large banks, private banks, and banks with low branch intensity enjoy a higher probability by adapting to new technology. Banks with a low market share are more concern about IB technology as a means to increase their market share by attracting more and more customers through this new channel of delivery. Some analysts argue that IB has revolutionizedthe modern banking industry.Carlsonet al. (2000) point out that some banks haveutilized the Internet as simply adding another delivery channel of remote banking to existing channels such as automated teller machines (ATMs) and telephone banking. However, in a worldthat is increasingly globalized, IB is gaining ground as a new opportunity for banking institutions. These new opportunities and challenges have meant the rise of new competitors in the global banking market (Suganthiet al., 2001). 
Utilization of information and communication technology concepts, techniques, policies, and implementation of strategies to banking services have developedin to a matter of fundamental importance and concern to all banks in Sri Lanka. The advancement in technology has played an important role in improving service delivery standards in

Corresponding Author:-WasanthaPremarathne.

n the

Address:-Department of Management and Finance, KotelawalaDefence University, Ratmalana, Sri Lanka. us on

banks indicate that the majority of banking customers in SrI Lanka do not use Internet Banking (IB) services provided by their banks. When we compare with the development of information and communication technology in the countryas depicted by the Telecommunication and Regulatory Commission of Sri Lanka, Central Bank of Sri Lanka and the World Bank, the demand for IB facilities is not at a notable level.In addition, IB providers in Sri Lanka do not pay adequate attention to increase the awareness of IB among their customers. Therefore, it is important to identify and analyzefactors affecting the adoption of IB in Sri Lanka for the betterment of the customers and providers.

\section{Review of literature:-}

IBcan be identified as a set of technological tools that offers a financial institution for its customers to make banking transactions via computers using an Internet connection. Ongkasuwan\&Tantichattanon (2002) defined IB as a banking service that allow customers to access and perform financial transactions on their bank accounts with their computers via an Internet connection. IB includes a system that enables customers of financial institutions, individuals, or businesses to access accounts, transact business, or obtain information on financial products and services on public or private networks including the Internet (Khan, 2007). Kim et al. (2006) defined IB as an act of conducting financial intermediation on the Internet. The U.S. Office of the Comptroller of the Currency (1999) has introduced three types of IB: Informational, Communicative, and Transactional.

Mansumitrchiand AL-Malkawi (2011) highlighted eight characteristics of the adoption of IB, namely; difficulty, trust, compatibility, third party concerns, human contact, and social influence, security, and computer proficiency. Purpose of their research was to examine factors underlying the adoption characteristics of IB by Mexican bank customers. The resultsindicated that adopters and non-adopters differed in their attitudes toward four attributes of the adoption: difficulty, trust, compatibility, and human contact. Human or physical contact during banking transactions was considered important for non-adopters. The study of Nathet al. (2001) focused on the effect of IB on strategic and operational dimensions of banks. Strategic dimensions include issues such as threats by e-banks and the need to offer IB operational issues including encountering the provisions of a better customer service, lowering transaction costs, and providing additional financial services to customers. From an operational perspective, this research indicated that banks with web-based banking realize significant benefits.

Amin (2007) developed a technology acceptance model for IB, a conceptual framework, to explain the factors influencing undergraduate students' acceptance of IB in Malaysia. The theoretical framework of the research was based on modified version of the Technology Acceptance Model (TAM). The model employs perceived usefulness (PU), perceived ease of use (PEOU), perceived credibility (PC), and computer self-efficiency (CSE). The results suggest that PU, PEOU, and PC had a significant relationship with behavioral intention. Chan \& Lu (2004) investigated adoption/use behavior within the context of Hong Kong IB services. The results revealed that both subjective norm and computer self-efficacy indirectly play significant roles in influencing the intention to adopt IB. Perceived ease of use had a significant indirect effect on intention to adopt/use through perceived usefulness, while its direct effect on intention to adopt was insignificant.

Hamadi (2010) demonstrates the existence of a causal relationship between perceived quality, satisfaction, and commitment in the context of online banking. The results indicate that the perceived quality heavily influences the commitment of customers and this effect is direct and not mediated by satisfaction. Singhal\&Padhmanabhan (2008) stated that over 50 percentof the total number of respondents agreed that IB is a convenient and flexible method of banking that involves various transaction related benefits. Thus, providing IB is increasingly becoming a "need to have" than a "nice to have" service.

Khan \&Emmambokus (2011) assessed factors that contribute to the adoption of IB in Mauritius. They concluded that factors such as age, income, service usefulness, risk factor, checking account frequency, and Internet location are the main determinants of online banking. Banks should implement more marketing strategies to enhance IB usage and educate the public, specially low and middle-income earners, and senior citizens about the benefits of this 
service. They should also make available more computers and qualified staff to explain about different bank formalities and websites. Khan \&Emmambokus (2011) found that demographic variables were insignificant, whereas Chang (2006) realized that except age, traditional demographic variables such as sex, education, marital status, personal income level, housing type, and residential location are not relevant indicators to decide whether IB will be chosen or not. Hamid et al. (2007) compared IB systems in Malaysia and Thailand. Using comparison as the theoretical base, secondary data were used to determine differences between both countries with respect to IB. Lack of effort on educating consumers about the benefits of IB has been further affected the usability of IBin both countries. A low level of connectivity and the concern over the security have contribute to impede the growth of IB.

Mattilaet al. (2003) pointed out that IB is the third popular mode of payment among mature customers in Finland.Moreover, household income and education have a significant effect on adopting the Internet as a banking channel; thus, over 30 percent of wealthy and highly educated mature males made e-bankingas their primary mode of making payments. Perceived difficulty in using computers combined with the lack of personal service in ebanking were the main barriers of adoptingIB among mature customers. Results of the present study confirmed that mature customers are late adopters of IB.

Samphanwattanachai (2007) stated that the objectives, goals, and information technology infrastructure of a bank are the main factors that influence the adoption of IBbycommercial banks. The number of Internet users, trust, and security are the main factors influencing IB adoption by the customers.

Meanwhile, Lichtenstein\& Williamson (2006) suggested that convenience is the main motivator for consumers to rely on the Internet, while a range of other influential factors may be modulated by banks. The findings also highlight increasing risk acceptance by consumers concerning Internet based services and the growing importance of offering deep levels of consumer support for such services. Gender differences are also highlighted. Banks must first draw banking consumer attention to the IB service, before consumersconsider IB. However, unless the consumer has a high level of Internet accessibility at home or at work, it is unlikely he/she will consider using IB.

Ok \& Shon (2006) identified that IB users' attitudesand argue that their perceived behavioral control play a vital role in influencing the behavioral intention of IB usage in South Korea. Another study by Suganthiet al. (2001) finds that educated young people and most affluent of the population are more likely to adopt IB. Moreover, this study points out that Internet accessibility, awareness, attitude towards change, computer and Internet access costs, trust in one's bank, security concerns, ease of use, and convenience are the major factors influencing the adoption of IB services in Malaysia.

Ezeet al. (2011) revealed that perceived ease of use, perceived usefulness, relative advantage, self-efficacy, perceived credibility, and trial ability tend to influence consumers to adopt IB. Hassanuddinet al. (2012) explored the factors affecting the acceptance of IB services provided by Bank Rakyat in Malaysia. Findings revealed that the respondents having an efficient Internet connection are about six times more likely to use IB services, compared to those with low Internet connection. Thulani\&Tofara (2009) explored the extent of adoption and usage of IB by commercial banks in Zimbabwe and investigated the challenges they faced in the adoption of this technology. Overall, the results showed that, while the majority of banks in Zimbabwe have adopted IB, usage levels have remained relatively low, as not many customers use this innovation in Zimbabwe. Regarding the challenges faced by banks in the adoption of IB, compatibility with existing legacy systems, cost of implementation, and security concerns ranked high.

MusiimeandRamadhan (2011) suggest that IB service providers ought to look out for indicators of innovative ways of creating awareness about the service through participation in trade organizations, exhibitions, and adoption of new technologies of IB. Cooper (1997) reports that the ease of using an innovative product or a service is one of the three important characteristics for its adoption from the customers' perspective. The user friendliness of the domain names and navigation tools available in the website are important determinants for ease of use, in addition to content of the web and its design.

Doll et al. (1995) found that product information content and its amount of product information, product information format, language, and the site layout have an impact on consumers' perception of the user friendliness of an IB site. Guru (2000) argue that designing websites with appropriate use of the graphical user interface is also considered as an important determinant. Further, they concluded that some consumers are generally reluctant to 
adopt new technology. Thus, technology phobia can also be a factor affecting customer adoption of IB. Kim et al. (2006) investigate determinants of IB adoption based on an individual's benefits and costs of adopting IB. Furthermore, this study reveals that the consumers' ability, attitude, opportunity, and cost of time play a significant role in the decision of adopting IB and younger and educated consumers are more likely to adopt IB.

\section{Methodology:-}

Sample and Data:-

Primary data were collected through semi-structured interviews and a questionnaire based customer survey of the selected banks in Sri Lanka: a private bank, a government bank, and a foreign bank in Sri Lanka. The sample of IB users and non-IB users for this researchwere selected via the convenience sampling method. Thesample consists of 120 IB users and 120 non-users. Secondary data were obtained from the publications of Ministries of Technology and Research, relevant bank publications, and annual reports of the Central Bank of Sri Lanka.

\section{The Econometric Model:-}

Based on available literature, an econometric model was developed to identify the factors and to capture their impact on the demand for IB. Kim et al. (2006) pointed out that a consumer will accept a new product (service) if the difference between the utility of the new service (product) and the exiting one exceeds some threshold value ( $\Psi>0$ ) ;

(Utility of the new service - Utility of the old service) $>\Psi$

Consumers maximize their utility within a subset for money transactions;

$\operatorname{Max} \mathrm{U}_{\mathrm{i}}=f\left(\mathrm{X}_{\mathrm{i}}, \mathrm{T}_{\mathrm{i}}, \mathrm{P}\right)$

Where $X_{i}$ is a vector of inputs for different services for technology $i, T_{i}$ is a vector of inputs of time for technology $i$, and $\mathrm{P}$ is a proxy for preference for new and old technologies.

The internet adoption function can be developed by substituting the utility function into equation (1) as follows:

$\left[f\left(\mathrm{X}_{\mathrm{i}}, \mathrm{T}_{\mathrm{i}}, \mathrm{P}\right)+\varepsilon_{1}\right]-\left[f\left(\mathrm{X}_{\mathrm{i}}, \mathrm{T}_{\mathrm{i}}, \mathrm{P}\right)+\varepsilon_{2}\right]>\Psi$

Where $\varepsilon_{1}$ and $\varepsilon_{2}$ are the effects of unobserved factors and if the difference between the unobserved factors, $\varepsilon_{1}-\varepsilon_{2}=\chi$, Thenequation (3) can be rewritten as follows:

$-\chi<\mathrm{U}^{*}$

Where

$\mathrm{U}^{*}=\left[f\left(\mathrm{X}_{\mathrm{i}}, \mathrm{T}_{\mathrm{i}}, \mathrm{P}\right)+\varepsilon_{1}\right]-\left[f\left(\mathrm{X}_{\mathrm{i}}, \mathrm{T}_{\mathrm{i}}, \mathrm{P}\right)+\varepsilon_{2}\right]-\Psi$

Based on the methodology proposed by Kim et al. (2006), this study employs the following model to find out which consumers are more likely to adopt IB. The dependent variable (DB) is a binary choice and it can be either 1 or 0 . Therefore, the model has a probability function as follows:

$\mathrm{DB}=f(\mathrm{X})+\mu$, where $\mathrm{X}$ represents the vector of explanatory variables

If $\operatorname{Pr}\left(-\lambda<\mathrm{U}^{*}\right)$ then $\mathrm{DB}=1$; IB is adopted by the consumer and

$1-\operatorname{Pr}\left(-\chi<\mathrm{U}^{*}\right)$ then DB $=0$; IB is not adopted

The functional relationship between the dependent variable and explanatory variables can be written as follows:

$\mathrm{DB}=f(\beta \mathrm{X}+\mu)$

Where

$\mathrm{X}=$ Vector of explanatory variables $=\mathrm{AG}, \mathrm{GE}, \mathrm{MS}, \mathrm{ED}, \mathrm{PR}, \mathrm{DS}, \mathrm{IN}, \mathrm{SE}, \mathrm{AW}, \mathrm{TR}$

Thus, the econometric model is as follows:

$D B_{i}=L_{i}=\left[P_{i} /\left(1-P_{i}\right)\right]=\beta_{1}+\beta_{2} A G_{i}+\beta_{3} G E_{i}+\beta_{4} M S_{i}+\beta_{5} E D_{i}+\beta_{6} P R_{i}+\beta_{7} D S_{i}+\beta_{8} I N_{i}+\beta_{9} S E_{i}+$

$\beta_{10} A W_{i}+\beta_{11} T R_{i}+u_{i}$

Where;

$\mathrm{DB}=$ Demand for IB $(1=$ users, $0=$ non-users $)$

$\mathrm{AG}=$ Age

$\mathrm{GE}=$ Gender

MS = Marital status

$\mathrm{ED}=$ Educational background

$\mathrm{PR}=$ Incentives given by the bank to promote IB

$\mathrm{DS}=$ Distance to the bank branch 
$\mathrm{IN}=$ Income

$\mathrm{SE}=$ Security

AW=Awareness

TR=Trust

\section{Data analysis and Results:-}

Cronbach Alpha value of 0.817 indicates that the questionnaire used to collect data on banking customers' opinion is highly reliable. Often itis argued that demographic differences exist between IB users and IB non-users. It is also believed that the younger generations who are more computer literate and have an affinity to the web are more likely to adopt IB.

Education level and income level have a significant effect on the adoption of IB. Thus, the demographic features of the IB users and the IB non-users in the sample respondents were analyzed, and no significant difference found between mean ages of the two groups. The mean age of IB non-users was about 35 years and of IB users was about 34 years; 43 percent of IB users are working in the private sector. However, the two groups are not equal in terms of level of education. One noticeable factor is the significant proportion (27\%) of IB non-users among those with only secondary education. Moreover, the average monthly income produced a significant difference. The mean monthly income of the IB users was Rs. 59908.33while for IB non-users it was Rs. 40341.67, and IB customers have more than one type of account. Thus, 46 percent of IB customers hold accounts in terms of saving, current, and term deposits. A significant feature is that 89 percent of IB non-users have only savings accounts. None belonging to either categoryuse current accounts only.

As the study reveals, 30 percent of the IB users utilize IB facilities between 9am and 12pm. IB usage between $2 \mathrm{pm}$ and $5 \mathrm{pm}$ is at a significant level as 27 percent of the customers use IB during that time. The time duration between $5 \mathrm{pm}$ to $8 \mathrm{pm}$ represents the lowest level (two percent) of IB usage. The sample of IB users reveals that 63 percent of customers use IB facility two to six times per week. Customers using IB facility daily is only 13 percent.

One of the main factors which would obstructconsumer adoption of IB is the cost factor. Two types of costs are associated with IB. First, the normal cost associated with the computer and Internet connections, and secondly, the bank fees and charges. If consumers are to use new technology, such a technology must be pricedreasonably in relation to alternatives. Otherwise, the acceptance of new technology may not be viable from the standpoint of the consumer. In view of the encouragement of Sri Lankan governmentto move towards the digital era, essential costs (access and connection) areheldat a minimum. As per the opinion of IB users, the cost of computers is a determinant of IB adoption with a 32.04 percentage. Bank charges are anotherconcerned factor for 87.34 percent among IB nonusers.

Reluctance to change is another factor influencing the adoption of a new product, particularly if the existing mode of service or product delivery adequately fulfils consumer needs. In the context of IB, telephone banking and mini branches are the existing alternative methods of transacting banking business for the customers those who want to change their present ways of operating and to engage in new technology, and their specific needs must be satisfied. If not, consumers may not be willing to change from the present ways of operating. Many ways can be introduced to overcome the reluctance to change;Provision of personalized customer service personnel to assist consumers during performing transactions via the Internet and providing specific value added services currently not provided through traditional banking channels could help reduce customer reluctance to change. It is prominentthat the opinion of IB non-users on willingness to adopt technology enhancement and attitude towards change has an impact of about 76 and 65 percentages respectively, with regard to adopting new banking technologies among IB non-users.

Availability of access to the Internet and Internet connection speed are essential prerequisites to adopt IB. The more widespread the access to computers and to the Internet, the greater the possibility of using IB. IB non-customers of this research opine that availability of access to the facility has a greater impact over IB adoption (71.11\%). A vast majority of bank customers would still prefer personal interactions during their bank transactions and the personal touch of officers and managers adds value to each transaction. In the Sri Lankan context, it is evident that the personal relationship between customers and bankers transcends many boundaries, especially in rural areas. The survey reveals that the degree of importance of preference for personalized services on adopting IB is about 84 percent as per the opinion of IB non-users. 
The most influencing factors for not adopting IB services is the security of IB (71.67\%) and poor awareness on IB services $(65.83 \%)$. Further, a majority of IB non-users concernon providing access of their financial details for third parties. The absence of the human element (people) and face-to-face interaction are significant factors for not adopting IB services provided by their banks.

The purpose of using aLogit Model was to examine and analyze the impact of selected demographic and other variables on demand for IB in the selected banks. Table 1 present the Logit estimates of the model.

Table 1:-Logit estimates for ungrouped binary data without outliers.

\begin{tabular}{|c|r|r|r|r|}
\hline Variable & Coefficient & Std. Error & z-Statistic & Prob. \\
\hline AG & $-0.262553^{*}$ & 0.054927 & -4.779986 & 0.0000 \\
\hline GE & -0.221880 & 0.438233 & -0.506307 & 0.6126 \\
\hline MS & $1.662916^{*}$ & 0.580714 & 2.863572 & 0.0042 \\
\hline ED & $0.559911^{*}$ & 0.282648 & 1.980948 & 0.0476 \\
\hline PR & $-0.346694^{*}$ & 0.119885 & -2.891884 & 0.0038 \\
\hline DS & $-0.112038^{* *}$ & 0.066331 & -1.689076 & 0.0912 \\
\hline IN & $7.76 \mathrm{E}-05^{*}$ & $1.73 \mathrm{E}-05$ & 4.482734 & 0.0000 \\
\hline AW & $-0.244077^{* *}$ & 0.128693 & -1.896576 & 0.0579 \\
\hline TR & $-1.114158^{*}$ & 0.197259 & -5.648191 & 0.0000 \\
\hline C & $15.63985^{*}$ & 2.871321 & 5.446917 & 0.0000 \\
\hline Mean dependent var & 0.508547 & S.D. dependent var & 0.500999 \\
\hline S.E. of regression & 0.331335 & Akaike info criterion & 0.754653 \\
\hline Sum squared resid & 24.59143 & Schwarz criterion & 0.902316 \\
\hline Log likelihood & -78.29442 & Hannan-Quinn criter. & 0.814191 \\
\hline Restr. log likelihood & -162.1623 & Avg. log likelihood & -0.334592 \\
\hline LR statistic (9 d.f.) & 167.7357 & McFadden R-squared & 0.517185 \\
\hline Probability(LR stat) & 0.000000 & & \\
\hline Obs. with Dep=0 & 115 & Total obs. & \\
\hline Obs. with Dep=1 & 119 & \multicolumn{3}{|}{} \\
\hline
\end{tabular}

* Significant at 0.05 significance level

** Significant at 0.10 significance level

Source: Survey data

The JB test of normality is a test of the joint hypothesis that Skewness and Kurtosis are 0 and 3 respectively. Value of JB statistics is expected to be zero. Since the JB statistic of the Logit model is 8886.494 and the $p$ value is zero, the residual term is not normally distributed (Figure 1).

Figure 1:- Histogram of the residuals of the Logit Model and the Jarque-Bera statistic

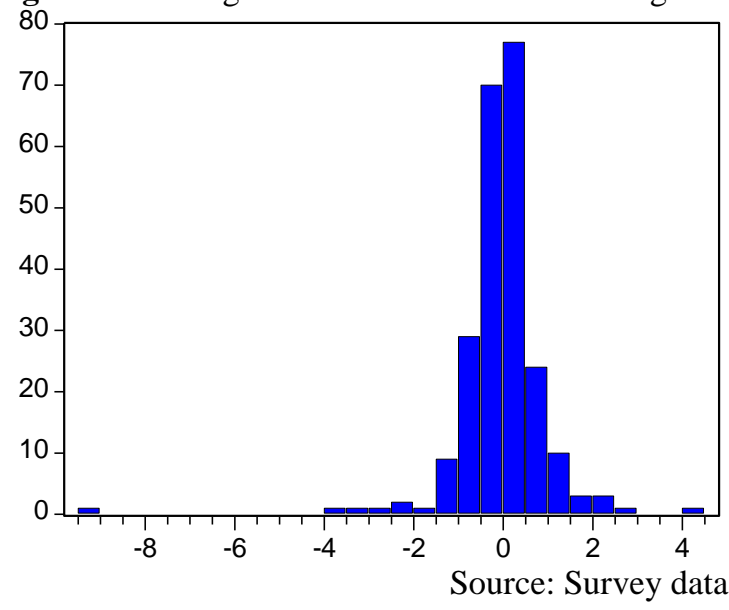

Series: Standardized Residuals

Sample 1234

Observations 234

Mean $\quad-0.033461$

Median $\quad 0.026350$

Maximum $\quad 4.058568$

Minimum $\quad-9.216066$

Std. Dev. $\quad 1.013969$

Skewness $\quad-3.062058$

Kurtosis $\quad 32.56232$

Jarque-Bera $\quad 8886.494$

Probability $\quad 0.000000$ 
The assumption normality of the error term is not essential if the sample size is large. Therefore, the usual test procedures are still valid asymptotically. Value of the $R_{M c F}^{2}$ in the Logit model is 0.52 ; since the dependent variable in the Logit model takes a value 1 or zero, if the predicted probability is greater than 0.5 , it is classified as 1 , but if it is less than 0.5 , it is classified as 0 . However, in the binary regression model, the goodness of fit is of secondary importance.

Likelihood ratio (LR) statistics with 9 degrees of freedom is 167.7357 and probability (LR stat) is 0.000000 . Together, all variables have a significant impact on the final grade, as the LR statistics is about 167.74 , whose $p$ value is about zero, and all coefficients are simultaneously equal to zero. However, coefficient of Gender (GE) is not statistically significant.

Each slope coefficient in the estimated regression model is a partial slope coefficient and measures the change in the estimated model. Thus, the coefficient of variable education (ED) is 0.56 while other variables remain constant, which means if the value of ED increases by a unit, on average, the estimated variable will increase by about 0.56 units suggesting a positive relationship between the two. The coefficient of age (AG)indicates a negative relationship between age and IB adoption. A one-year increase in AG decreases the odds of adopting IB by a factor of 0.769 , adjusting for other explanatory variables.

There is a positive relationship between education level and IB adoption. The odds of IB adoption are 1.751 times the odds of IB non-adoption for each one level increase in ED, adjusting for other explanatory variables. The odds ratio of 0.7070 relevant to $\mathrm{PR}$ indicates a negative relationship between the opinion of customers on incentives given by the bank to promote IB and IB adoption. For one unit increase in the degree of opinion on incentives, the odds of IB adoption is lower by 29.30 (=100-70.70) percent, adjusting for other explanatory variables. The odds ratio of 1.000 relevant to income (IN) indicates that one unit change in income results same probability of IB adoption and IB non-adoption, adjusting for other explanatory variables.

There is an inverse relationship between IB adoption and opinion on the degree of importance of trust. For one unit increase in the degree of opinion on trust, the odds of IB adoption is lowered by $67.18(=100-32.82)$ percent, adjusting for other explanatory variables. The antilog of the marital status (MS) coefficient of 1.662916 is 5.274

$\left(\approx \mathrm{e}^{1.662916}\right)$, which suggests that married customers are more than 5 times likely to get registered for IB services than customers who are not married, while other things remains same.

\section{Conclusion:-}

Internet bank users appear to represent amore affluent stratum of the Sri Lankan society. This researchidentified that the cost of being innovative (cost of Internet connection, cost of computers, etc.) have no significant influence on the adoption of IB. Consumers experience a service or a process of knowledge before they are ready to adopt a new product or a service. Adoption of such innovation will materialize only when the consumer becomes satisfactorily conversantof the real actions involved in the process. Techno-phobia is an important determinant of the amount of IB users, where the propensity to adopt technology enhancement and the attitude towards change plays significant roles. Another important aspect of the adoption of IB is that the availability of access to the Internet.

Alternatively, many customers lack the basic knowledge needed to adopt IB, and they feel the term "Internet" implies insecurity because other people can hack information. Mostly, IB is not an important facility to many customers as their bank branch of transaction remains in the close vicinity. Besideslack of popularity of banking habits among people is extremely decisive in adopting IB in Sri Lanka.Consumers who opted not to adopt IBstated they were happy with their existing banking methods and expressed concern over uncertain online security. Traditional demographic variables such as education, marital status, and personalincome level are the relevant decisive indicators of the acceptance of IB, with the exception of gender. In Sri Lanka, banks as the internet banking service providers, and customers as the beneficiaries, are still not reaping the real benefitsof internet banking.

\section{References:-}

1. Amin, H. (2007). Internet banking adoption among young intellectuals,Journal of Internet Banking andCommerce, 12 (3), pp. 1-13.

2. Arslan, A. (2012). The effect of socio-economic and demographic factors of Turkish provinces on the number of active customers using internet banking. International Journal of Human Sciences, 9(2), pp. 288-302. 
3. Guru, B.K. (2000). E-banking developments in Malaysia: prospectsand problems. Journal of International Banking Law, 15(10), pp. 250-256.

4. Carlson, J., Furst, K., Lang, W.W.\&Nolle, D.E. (2000). The new economy: what has changed, and the challenges for economic policy. Society of Government Economists Conference 2000, 17 Nov 2000, Washington, DC.

5. Chan, S.C. \& Lu, M. T. (2004). Understanding internet banking adoption and use behavior: a Hong Kong perspective. Journal of Global Information Management, (12), pp. 21-43.

6. Chang, Y.T. (2006). Dynamics of internet banking: lessons from Korea. CCP working paper 06-3.The ESRC Centre for Competition Policy (CCP), University of East Anglia.

7. Cooper, R.G. (1997).Examining some myths about new product winners. In: Katz, R. (eds.) The Human Side of Managing Technological Innovation. Oxford. pp. 550-60.

8. Doll, W.J., Raghunathan, T.S., Lim, J.S.\& Gupta, Y.P. (1995). A confirmatory analysis of the user information satisfaction instrument. Information Systems Research, 6(2), pp. 177-88.

9. Eze, U.C., Manyeki, J.K., Yaw, L.H. \&Har, L.C. (2011). Factors affecting internet banking adoption among young adults: Evidence from Malaysia. International Conference on Social Science and Humanity, IPEDR, (5).

10. Hamadi, C. (2010). The impact of quality of online banking on customer commitment. Communications of the IBIMA, pp. 1-8.

11. Hamid, M.R.A., Amin, H., Lada, S., \& Ahmad, N. (2007).A comparative analysis of internet banking in Malaysia and Thailand. Journal of Internet Business, (4), pp. 1-19.

12. Hassanuddin, N.A., Abdullah, Z., Mansor, N., \& Hassan, N.H. (2012). Acceptance towards the use of internet banking services of cooperative bank. International Journal of Academic Research in Business and Social Sciences. 2(3), pp. 135-147.

13. Khan, N.M. \&Emmambokus, N. (2011). Customer adoption of internet banking in Mauritius. International Journal of Business Research and Management, 2(2), pp. 53-58.

14. Khan, S.K. (2007).Adoption issues of internet banking in Pakistani's firms. Lulea University of Technology, Sweden.

15. Kim, B.M., Widdows, R. \&Yilmazer, T. (2006).The determinants of consumers' adoption of internet banking: factors determining consumer adoption of internet banking. [Online]. Available on: http://papers.ssrn.com.

16. Lichtenstein, S. \& Williamson, K. (2006). Understanding consumer adoption of internet banking: an interpretive study in the Australian banking context. Journal of Electronic Commerce Research, 7(2), pp. 50-66.

17. Malhotra, P. \& Singh, B. (2007). Determinants of internet banking adoption by banks in India. Emerald Group Publishing Limited, (17).

18. Mansumitrchi, S. \& AL-Malkawi, H.A.N. (2011). Factors underlying the adoption of online banking by Mexican Consumers.International Journal of Business and Management, 6(9), pp. 155-169.

19. Mattila, M., Karjaluoto, H., \&Pento, T. (2003). Internet banking adoption among mature customers: Early majority or laggards? Journal of Services Marketing, 17(5), pp. 514-528.

20. Musiime, A.\&Ramadhan, M. (2011).Internet banking, consumer adoption and customer satisfaction. African Journal of Marketing Management, 3(10), pp. 261- 269.

21. Nath, R., Schrick, P., \&Parzinger, M. (2001). Bankers' perspective on internet banking. E-Service Journal, 1(1), pp. 21-36.

22. Ok, S. \& Shon, J. (2006). The determinants of internet banking usage behavior in Korea: A comparison of two theoretical models. Communications of the IBIMA, (9), pp. 252-263.

23. Ongkasuwan, M. \&Tantichattanon, W. (2002).A comparative study of internet banking in Thailand. [Online] Availableon:http://www.ecommerce.or.th/nceb2002/paper/55-A_Comparative_Study.pdf[Accessed $15^{\text {th }}$ October 2013].

24. Samphanwattanachai, B. (2007).Internet banking adoption in Thailand: A Delphi Study. Proceedings of the 24th South East Asia Regional Computer Conference, Bangkok, Thailand.

25. Singhal, D. \&Padhmanabhan, V. (2008). A study on customer perception towards internet banking: Identifying majorcontributing factors. The Journal of Nepalese Business Studies, 1(1), pp.101-111.

26. Suganthi, R., Balanchander, K. G., and Balanchandran, V. 2001. Internet banking patronage: An empirical investigation of Malaysia, Journal of Internet Banking and Commerce, 6(1), pp. 1-10.

27. The Office of the Controller of the Currency (1999). Internet banking: A controller's handbook. [Online] Available onhttp://www.occ.treas.gov/handbook/intbank. Pdf. pp. 4-12[Accessed on $16^{\text {th }}$ March 2013].

28. Thulani, D. \&Tofara, C. (2009). Adoption and use of internet banking in Zimbabwe: An exploratory study. Journal of Internet Banking and Commerce, 14(1), pp. 2-13. 
29. Weerasekara, S. (2011). An empirical study on slow and limited adoption of internet banking by Sri Lankan customers.International Conference on Industrial and Information Systems (ICIIS), (6), pp. 404- 409. 